\title{
Water Management and Technological Advancement of the Ancient Tamils in Irrigation Practices: An Assessment from Historical Evidences
}

\author{
K. Madhusudharsanan ${ }^{1 *}$ and S. Murugaiyan ${ }^{2}$ \\ 'Assistant Professor and Head, Department of History; \\ sudharsancnc@gmail.com \\ 2Ph. D. Research Scholar, Chikkaiah Naicker College, Erode - 638004, Tamil Nadu,
}

India

\begin{abstract}
Tamil Nadu has been primarily an agricultural country. Nowadays, much attention is being given to trace out the glorious past, especially the ancient irrigation management and technology practiced in the state. Limited sources are available to know the best practices of the irrigation system during this period. The Emperors of ancient period not only patronized irrigation but also had given responsibilities to the village institutions for the apt management and appropriate uses of water bodies in the state. The maintenance work called as Kudimaramat system was functioned well. Sluice technology found in Tamil land discloses the scientific advancement of the society then. We could learn the environmental aspects, particularly the knowledge they had given to us for choosing the area of the construction of tanks as well as the materials to be used for long life of the dam without any damage even in natural calamities. Village societies were the authorities of the water rights. However, the changes in landownership pattern and the introduction of canal irrigation paved the way for the decline of tank irrigation in Tamil Nadu. This study made an attempt to highlight the irrigational practices which existed in the ancient Tamil Nadu.
\end{abstract}

Keywords: Anicut, Kudimaramat, Water Rights, Water Management, Technology

\section{Introduction}

Tamil Nadu has been primarily an agricultural country. Nowadays, much attention is being given to trace out the glorious past, especially the ancient irrigation management and technology practiced in the state. Limited sources are available to know the best practices of the irrigation system during this period. Ancient emperors not only patronized irrigation but also had given responsibilities to the village institutions for the apt management and appropriate uses of water bodies in the state. The maintenance work called as Kudimaramat system was functioned well. Sluice technology found in Tamil land discloses the scientific advancement of the society then. We could learn the environmental aspects, particularly the knowledge they had given to us for choosing the area of the construction of tanks as well as the materials to be used for long life of the dam without any damage even in natural calamities. Village societies were the authorities of the water rights. However, the changes in landownership pattern and the introduction of canal irrigation paved the way for the decline of tank irrigation in Tamil Nadu. This study made an attempt to highlight the irrigational practices which existed in the ancient Tamil Nadu.

*Author for correspondence 


\section{Review of Literature}

C. J. Baker's An Indian Rural Economy (1800-1955): The Tamil Nadu Countryside, Kathleen Gough's Rural Society in South East India, John Mencher's Agriculture and Social structure in Tamil Nadu, K. Palanisami's Tank Irrigation in Tamil Nadu (Revival for Prosperity), David Ludden's Peasant History of South India, Gomathinayagam's History of Irrigation in Tamil Nadu, Srinivasan's Irrigation and Water supply South India 200 BC to 1600 AD, K. Rajan's Ancient Irrigation Technology in Tamil Nadu, Dharmakumar's The Cambridge Economic History of India,1757-1970, A. Mohanakrishna's History of Irrigation Development in Tamil Nadu, B. D. Dhawan's Irrigation and Agriculture Development in India, Arun Bandopadayay's Agrarian Economy of Tamil Nadu (1800-1855), Neel P. Verma's Irrigation in India, V. M. Jha's Irrigation and Agriculture Development are the important studies on the subject of Irrigation Development undertaken in the pre and post- independence period have been reviewed.

\section{Methodology}

In pursuing the study, archival sources have been used to a great extent. Manuals and gazetteers, essays and articles in contemporary journals, and the books appended to the notes and references form the secondary sources of the study. Apart from narrative method, critical analysis has also been adopted.

It is noted that certain variety of irrigated cultivation can be traced back as early as Sangam Period (300 B.C A.D 300). Sangam literature mentions paddy cultivation both in terms of river and tank irrigation ${ }^{1}$. Literatures like Thirukural and Silappadikaram deal with agriculture and the irrigation practices. Thirukural points out a chapter for Uzhavu Cultivation. The Cauvery rises in Coorg, near Mercara which drains an area of 26,000 square miles, and enters the delta of Thanjavur. The Grand Anicut located 8 miles east of Tiruchirappalli divides into a number of minor channels to which irrigation has been practiced from time immemorial. Tradition gives credit for the construction of the first irrigation work in Thanjavur delta.
During the second century A.D, under the administration of Karikala Chola, the Grant Anicut was constructed on the river Cauvery. The credit for the construction and execution goes to then ruler of the Chola dynasty, Karikala Chola. The ruler took keen interest in agricultural development by providing extensive irrigation facilities in the delta regions. This Grand Anicut is a wonderful hydraulic structure built across Cauvery in its sandy bed even when the technology had not developed. However, there is no recorded information about this wonderful structure or the manner of its construction ${ }^{2}$.

\section{Construction of New Tanks}

The period of Kalabhras in Tamil land witnessed no recorded information pertaining to irrigation development. Pallavas were the pioneers, notably in the construction of tanks. Suitable attention was given to agriculture by the pallavas. Tanks namely Chitrameka Tataka, Parameswara Tataka, Vairamegha Tataka, Mahentra Tataka, Kanakavalli Tataka were their notable constructions. They were popularly called as 'kaduvettigal' in terms of their construction of new tanks and lakes³. The Chola Empire rose to power after the kalabhras with the intention of cultural and political expansionism. Much attention was given to renovation and reclamation of pools and lakes by the management of local administration. Paranthakan, (907-955 A.D) built Veera Chola Vadavarayar flowing north of Tanjore and Maadhurantaka. Rajaraja (985-955 A.D) built the Manniyaru flowing north of Konerirajyapuram and Uyyakondan Channel flowing through Tiruchurappalli town and Periyavaaikal ${ }^{4}$. Rajendra (1014-1044 A.D) built the Mudikondam Aaru branching off from Sundavaperumal koil. Rajendra also constructed 'Chola Gangam' in Gangai Kondacholopuram. This was popularly called as his "Watershed Victory Tower" in memory of his victory over the Ganaga rulers ${ }^{5}$. Veerarajendran (1063-1070 A.D) built the Veera Cholam Aaru branching off from the Cauvery near Mananjeri. Vikramachola (1118-1135 A.D) built the Vikrama Aru branching off from the Cauvery north of Kuttalam. For the expansion 
and the development of agriculture, they established separate Variyams or Boards to maintain irrigation facilities.

The Pandya region depended on rainfed reservoirs for irrigation. The present district of Madurai, Ramanathapuram, was once the major dry zone area of the Pandya country. Captain Horsley, a British engineer who worked in the southern districts of Tamil Nadu made the following statement while renovation work was undertaken in Kanayakumari District.

"In other countries and in India also, an engineer generally works on his own lines in developing any large scheme of irrigation and naturally credits his own skill and perseverance with the success of his undertaking. Here, however, I have no hesitation in saying that it has been an unmixed pleasure to me, from a professional point of view, to merely follow the lines of original constructors of the Pandyan Canal and Padmanabhapuram Puthanar, because the evidence of their skill and almost super human perseverance was so marked; and I have, in carrying out the works, felt contended and fully satisfied to follow the footsteps of those whom, I cannot but consider to have been masters in their art and facile pioneers in irrigation engineering" ${ }^{6}$.

(Source: Appadurai A. Travancre Manual vol. II page 102)

The above line clearly shows the knowledge and advancement of the Tamils than the West in irrigation management. Ancient Tamils not only built dams and tanks in Tamil Nadu, but also in foreign countries. The irrigation works of South East Africa and Philippines owes them to the Tamils according the H.W. Fleming, a German Historian,

"A very highly astonishing discovery of recent research is the remains of irrigation works in South East Africa which do not belong of the cultural influence of Egypt. Indian Dravidians who were pushed South by the Indo - Germans moved into South East Africa and built magnificent irrigation works that apparently helped terrace cultivation of paddy. Similar influence is visible in the Philippines. The voyage of the Dravidians to South East Africa and Philippines across ocean should be recognized as an achievement of high order."
Source: H.W Fleming in Wuesten, Deiche and Turbinen".

\section{Water Rights in Tamil Nadu}

During the ancient period Ur and Urar had the power to allocate and distribute water from irrigation sources. The inscription of Maran Sendan in 770 A.D describes that the Urar had sold land to Velsendil (name of a person) along with water rights specified for time duration. Similarly, when the land was sold or transferred to others, the water share also had been sold along with it. Inscription from Pudukottai district depicts this information?

"When the Urar of Alattur sold in auction to a dancing girl of the temple $1.6 \mathrm{ha}$. of land they also sold with the lands 16 naligais (6.4 hrs) of water out of 180 nalaigas ( 3 days) for which perumkumil nalaigas (Big sluice) was drawing water from tank". (Pudukottai inscription No. 666)

The present concept of water rights and riparian right had been existed in ancient Tamil $\mathrm{Nadu}^{8}$. After the decline of the Tamil Kingdoms, the feudal society dominated and gradually the popular village republics had been disintegrated. The newly emerged dynastic rule controlled all the lands and tied up with the relation of non-cultivating aristocrats in the villages for getting income.

\section{Classification of Water Rights}

The water rights are exercised in two ways. The first is having right on certain amount of water or shared right on water. The second one is exercising right over the tank. There were several components on water rights. The phrases like Kulamum_(tank), Kulakkalkalum (The outlet canals), Kulakarayum (embankment of the tank) Kulavayum (the channel of the tank), Kulavariyam (The channel brings water to the tank) indicate that the tank and the irrigated land was considered as a single unit ${ }^{9}$.

In Tamil Nadu the village societies had enjoyed water rights. Each and every village has its own jurisdiction to control and access water resources. The main assignments given to them were the maintenance of irrigation work, water sharing and problem solving in times of dis- 
putes and collection and imposition of penalties for the disengagement of irrigation work $^{10}$. The caste system interrupted and also decided the position of employment among the functionaries. For instance, the management work was assigned to an upper caste farmer whereas the labour work was normally given to a scheduled castes ${ }^{11}$.

\section{Kudimaramath System and its Decline}

Labourers employed in a land voluntarily were called as kudimaramath system. This system was on the path of decline from the middle of the $19^{\text {th }}$ century. The British government patronized the best practices of irrigation systems, especially the traditional system called Kudimaramat System for the welfare of the agricultural community. But, it did not get the desired results. The disintegration of village society and imposition of heavy taxes on land paved the way for its decline. Besides, the absentee of landlordism and decline in the power of the village headman were the subsidiary causes for the devolution of the Kudimaramat system. The British had manifested the system even after its decline ${ }^{12}$. Subsequently, the colonial government had undertaken some ameliorative measures for the revival of the age-old community labour system in the Madras Presidency. The first effort in this regard was made in the year 1955, the then collector of Thanjavur, who had prepared an irrigation Bill. The intention of this Bill was to restrict heavy damage to irrigation structures. However, legal measurers were not properly implemented in the Bill and thus it failed its objects. Consequently, in the year 1858, the Madras Compulsory Labour Act was passed. In this act, the very legal provisions were enacted for compulsory labour for certain aspects of maintenance and penalizing those who were in continues absence in the community labour. This act also failed to keep alive the kudimaramat system. Later, much attention was given by the Famine Commission of 1878 and the irrigation Commission of 1901. The government had also appointed a committee for the revival of the kudimaramat system. The study and suggestions of the committee was accepted and approved by the Government of India even after it received serious criticism ${ }^{13}$.

\section{Water Management}

In Tamil Nadu, water management prevailed during the ancient times. Many inscriptions give ample evidence in support of these facts. The time allocation was fixed for water flows from big sluice for a period of $3^{\star} 24(72$ minutes). The basic time measurement was poluthr amounting to 12 hours. Pandya King Sendan's inscription dated 770 A.D describes Kanikootrodu neer which denotes the quantity of water for irrigation in a stipulated time. Similarly, the words like Narkisaindavannam and 'Neerkeenthavannam_ represents the same meaning of water sharing. If any violations were made against any temple lands, social punishments were given severely.

There is one verse in the form of mathematical quiz in Kanakkathikaram named Neervazhi Sutram.

'Oru nalin nazhigai olla manathin

Varunazhikaiku eenthu manotharumilakkam

Sertharkku veranathu Innazhikaiku keenthu

Partha dinam peroo pahar'.

The above said lines give information about the method of calculation of irrigation. If a tank has a sluice that would irrigate the ayacut in 4 nazhigai (96 mintues) it was considered that one sluice would irrigate the ayacut is 6 nazahigai (144 minutes) ${ }^{14}$.

\section{Conclusion}

Tamils had the knowledge of irrigation practices and its management for agriculture from the earliest time. Decentralization of water management, kudimaramat system or community labour and the irrigation technology were the salient features of the Tamil people. During the British period, several ameliorative measures were undertaken to protect the native people from the onslaught of floods and famines. As a part of the precautionary measures, various irrigation projects particularly canal irrigation was encouraged in the state. It led to the decline of traditionally patronized tank irrigation in the state. 


\section{Notes and References}

1. Report of the Royal Commission of Indian Agriculture, Agricole Publishing Company, New Delhi; 1928. p. 328.

2. Shanmugam P. The Revenue System of the Cholas, Madras; p. 45

3. Carldwell R. A History of Tinnevelly, Asian Educational Services, New Delhi; 1982. p. 18.

4. Amalanathan CJ. Kalvettil Neerpasanam, Seminar on Inscriptions, Speeches and Papers, R. Rangasamy Books India Ltd.; p. 141-3.

5. The Hindu, Thanjavur; 2013 Feb 5.

6. Appadurai A. Travancore Manuel. Vol. II, p. 102.
7. Gomathinayakam, Ratnavel S.M. In Search of Ancient WisdomIrrigation Tanks, Dhan Foundation Madurai; 2006. p. 118.

8. South Indian Inscription, No. 236.

9. Rajan K. Ancient Irrigation Technology, Heritage India Trust, Thanjavur; 2008. p. 60.

10. Bandopadhyay A. The Agrarian Economy of Tamil Nadu (1820-1855), K. P. and Company, NewDelhi; 1992. p. 44.

11. Ibid.

12. Rajagopal A. States in perplexity, the Politics of Water Rights and System Turnover in Tamil Nadu, Madras: MIDS; 2002. p. 4-6.

13. Ibid.

14. Gomathinayakam, Ratnavel S. M. In Search of Ancient Wisdom-Irrigation Tanks, Dhan Foundation Madurai; 2006. p. 118. 